\title{
Evidence on result-based financing in maternal and child health in low- and middle-income countries: a systematic review
}

Nigel James ${ }^{1 *}$ (D) Kenny Lawson ${ }^{2,3}$ and Yubraj Acharya ${ }^{1}$

\begin{abstract}
Introduction: Result-Based Financing (RBF) is an umbrella term for financial mechanisms that link incentives to outputs or outcomes. International development agencies are promoting RBF as a viable financing approach for the realization of universal health coverage, with numerous pilot trials, particularly in low- and middle-income countries (LMICs). There is limited synthesized evidence on the performance of these mechanisms and the reasons for the lack of RBF institutionalization. This study aims to review the evidence of RBF schemes that have been scaled or institutionalized at a national level, focusing on maternal, newborn, and child health (MNCH) programming in LMICs.

Methods: A systematic literature review was conducted following the Preferred Reporting Items for Systematic Reviews and Meta-Analyses (PRISMA) guidelines. The authors identified and reviewed country-level RBF evaluation reports for the period between January 2000 and June 2019. Data were extracted from both published and gray literature on RBF application in MNCH using a predesigned matrix. The matrix headers included country of application; program setting; coverage and duration; evaluation design and methods; outcome measures; and key findings. A content thematic analysis approach was used to synthesize the evidence and emerging issues.

Results: The review identified 13 reports from 11 countries, predominantly from Sub-Saharan Africa. Performancebased financing was the most common form of RBF initiatives. The majority of evaluation designs were randomized trials. The evaluations focused on outputs, such as coverage and service utilization, rather than outcomes. RBF schemes in all 11 countries expanded their scope, either geographically or accordingly in terms of performance indicators. Furthermore, only three studies conducted a cost-effectiveness analysis, and only two included a discussion on RBF's sustainability. Only three countries have institutionalized RBF into their national policy. On the basis of the experience of these three countries, the common enabling factors for institutionalization seem to be political will, domestic fund mobilization, and the incorporation of demand-side RBF tools.
\end{abstract}

Conclusion: RBF evidence is still growing, partial, and inconclusive. This limited evidence may be one of the reasons why many countries are reluctant to institutionalize RBF. Additional research is needed, particularly regarding costeffectiveness, affordability, and sustainability of RBF programs.

Keywords: Result-based financing, Maternal and child health care, Low- and middle-income countries, Pay for performance, Institutionalization

\footnotetext{
* Correspondence: nmj5238@psu.edu

'Department of Health Policy and Administration, The Pennsylvania State

University, University Park, PA 16801, USA

Full list of author information is available at the end of the article
}

(c) The Author(s). 2020 Open Access This article is licensed under a Creative Commons Attribution 4.0 International License, which permits use, sharing, adaptation, distribution and reproduction in any medium or format, as long as you give appropriate credit to the original author(s) and the source, provide a link to the Creative Commons licence, and indicate if changes were made. The images or other third party material in this article are included in the article's Creative Commons licence, unless indicated otherwise in a credit line to the material. If material is not included in the article's Creative Commons licence and your intended use is not permitted by statutory regulation or exceeds the permitted use, you will need to obtain permission directly from the copyright holder. To view a copy of this licence, visit http://creativecommons.org/licenses/by/4.0/. 


\section{Introduction}

Result-Based Financing (RBF) is an umbrella term covering a number of financing instruments that align incentives to outcomes [1]. Common types of RBF include performance-based financing (PBF), usually referred to as "pay for performance" or P4P; user fees exemptions; voucher programs; and conditional cash transfers (CCTs). These innovative financing instruments utilize the provision of incentives to healthcare providers and/ or users to improve health outcomes.

The World Bank is leading the promotion and implementation of RBF projects in maternal, newborn, and child health $(\mathrm{MNCH})$ in low- and middle-income countries (LMICs). The World Bank is also managing the Health Results Innovation Trust Fund (HRITF), a multidonor trust fund. This fund is supported by the governments of Norway and the United Kingdom [2]. As of September 2016, the HRITF had committed US $\$ 385.6$ million for 35 RBF programs in 29 countries [3]. Increasingly, other bilateral, multilateral, and philanthropic agencies are channeling some of their funding via RBF [4].

From around the 2000s, the donor community has been funding RBF pilot projects in LMICs, particularly those experiencing a slow progress in the Millennium Development Goals (MDGs) related to maternal and child mortality [5]. RBF is now seen as a strategic health care financing mechanism with the potential to contribute to the achievement of universal health coverage (UHC) [6, 7]. $\mathrm{UHC}$ aims to enable all people to access the full spectrum of health care services while protecting them from financial risks associated with seeking these services [8].

Maternal mortality is unacceptably high with the vast majority of the deaths (94\%) occurring in low-resource settings [9]. Existing literature suggests that low utilization of $\mathrm{MNCH}$ services is due to financial barriers, particularly among the poor [10-12]. Leveraging on effective and efficient health financing models, such as RBF, can potentially increase utilization on the demand side, enhance quality on the supply side, and improve health outcomes. Furthermore, RBF approaches used in $\mathrm{MNCH}$ have demonstrated significant increase in coverage and utilization of services [13]. By channeling resources directly to the point of use, RBF mechanisms equip frontline health care providers and managers with the financial capacity and autonomy to institute structural improvements required at the health facilities level, which can eventually improve health outcomes.

Many countries, however, have not institutionalized RBF by integrating such schemes into their national health systems $[14,15]$. The reasons for the lack of integration are poorly understood. The aims of this study are to review the RBF schemes that have been scaled from an initial pilot - either geographically or by increasing the scope - and assess the evidence on effectiveness and cost effectiveness, including whether there are documented lessons on potential barriers and enablers to institutionalization. While strong evidence in favor of RBF may not necessarily translate into RBF institutionalization, an emerging body of literature from rigorous large-scale randomized trials has shown that policymakers are indeed receptive to such evidence [16]. Therefore, documenting evidence on the effect of country-level efforts can be an important step in determining the extent to which development agencies should continue to advocate for the institutionalization of RBF.

\section{Methods \\ Study design}

The authors conducted a systematic review following the Preferred Reporting Items for Systematic Reviews and Meta-Analyses (PRISMA) guide. The review is registered and published on PROSPERO, an international registry of systematic reviews (ID: CRD42019133119).

\section{Study setting}

This study focused on published and gray literature on country-level RBF evaluation reports. The authors reviewed evaluation reports for various RBF mechanisms being applied in $\mathrm{MNCH}$. Sources were limited to reports from LMICs, which were defined based on the World Bank's income-based classification [17]. The evaluation reports were predominantly from Sub-Saharan Africa.

\section{Study period}

$\mathrm{RBF}$ in $\mathrm{MNCH}$ in LMICs is a relatively new concept. Therefore, the authors reviewed RBF studies published between January 2000 and June 2019.

\section{Search strategy}

The authors retrieved published country-based RBF evaluation reports using the Web of Science, PubMed, and Google scholar databases following a PRIMSA guideline template (Fig. 1). Relevant records were obtained using the following predetermined search terms: (RBF "OR" Incentives schemes) "AND" (Maternal and Child Health Care "OR" Health Care "OR" Health) "AND” (RBF “OR" Output Based Strategies) "AND” (Impact in $\mathrm{MNCH}$ "AND” (RBF programs "OR" RBF projects "OR" Incentives based mechanics "OR" Health Financing "OR" PBF) "AND” (Low- and Middle-Income Countries "OR" Developing Countries).

\section{Inclusion and exclusion criteria}

The inclusion criteria were country-based evaluation reports published between January 2000 and June 2019 for any RBF type in LMICs targeting $\mathrm{MNCH}$ and sources being available in English. The exclusion criteria were RBF study evaluation protocols, RBF mechanisms targeting sectors other than $\mathrm{MNCH}$, and studies conducted in non-LMICs settings. 


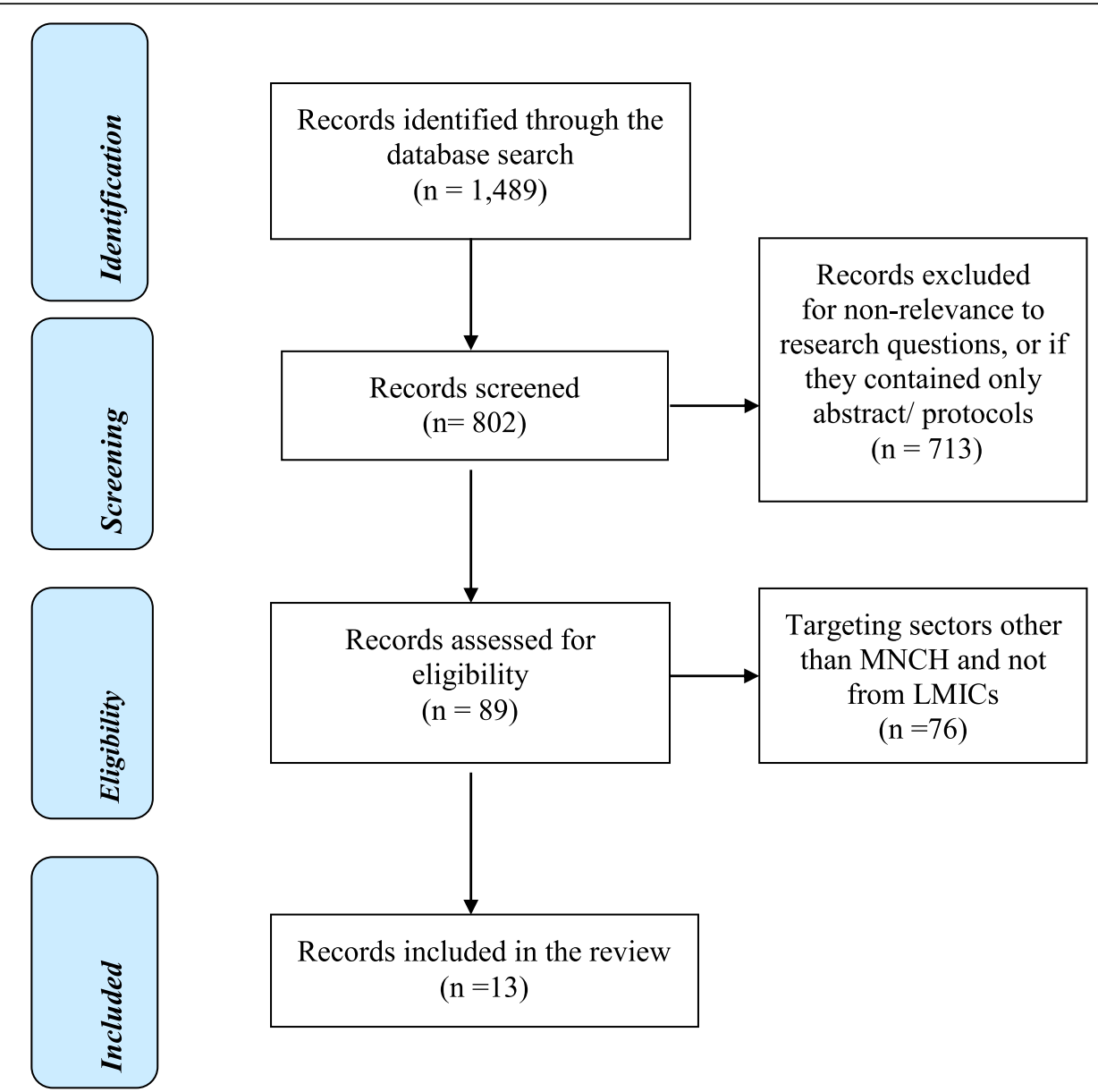

Fig. 1 PRISMA flow diagram for the evidence on RBF mechanisms on maternal, neonatal, and child health in low-and middle-income countries

\section{Data extraction and synthesis}

The data from eligible evaluation reports [13] were extracted into a predesigned matrix table. The data included country of application; program setting; program coverage and duration; type of evaluation and methods used; outcome measures; and key findings. The first author (NJ) drafted the consolidated matrix, with the remaining two authors (YA and $\mathrm{KL}$ ) assessing for consistency and accuracy. In order to evaluate the quality of the reports, the authors adopted the Cochrane Risk of Bias Assessment tool to assess potential selection, performance, and reporting bias. The first author assessed the level of bias (high, low, or unclear), and the coauthors reviewed the assessment. The overall level of bias reported for each study is based on the consensus of all three authors. The framework developed by Shroff and colleagues' on RBF scale-up was adapted to assess each country's institutionalization and scale-up progress [15].

\section{Results}

\section{Sample of studies}

The review retrieved 1489 records through the database search (Fig. 1). Of these, 802 were assessed for eligibility.
Out of these 802 records, 713 were either not relevant to the research question or did not meet the inclusion criteria, leaving 89 records. Seventy-six of these 89 studies were based on projects that targeted areas other than $\mathrm{MNCH}$ or were not conducted in a LMIC, yielding 13 studies for the current review. Of the 13 records, three were based on Rwanda and the remaining 10 countryreports were from Afghanistan, Argentina, Benin, Burundi, Cameroon, Democratic Republic of Congo, Mozambique, Zambia, Zimbabwe and Nigeria (Table 1). Table 2 shows each country's program scale-up level defined as either generation, adoption, or institutionalization. So far, Rwanda, Cameroon, and Burundi have institutionalized RBF as a national health financing policy.

\section{General features}

The program's implementation duration varied from two to five years. Zimbabwe and Benin reports were mid-line evaluations whereas the rest were end-line evaluations. Most of the studies were conducted as randomized trials; exceptions were those from Benin, Burundi, Mozambique, and Zimbabwe. In the absence of evaluation protocols to 
Table 1 Description of RBF evaluation reports including evaluation methods and key findings, by country

\begin{tabular}{llll}
\hline Country, Program Setting & Program coverage & Evaluation & Evaluation method and main Key evaluation findings \\
Authors, & timing & outcome measures \\
Year & and & \\
& program & \\
& duration & \\
& & \\
& & \\
\hline
\end{tabular}

Afghanistan A supply side P4P on 422 health facilities (230Cyrus et al. selected MNCH indicators in Intervention, - 212-

(2015) [19] 11 out of 34 provinces. Incentives tied to quantity of care delivered were provided quarterly to healthcare workers
Nationwide

Argentina Gertler et al. (2014) [20]

Benin

RBFHealth

(2014) [21]
Supply side P4P national

program based on an

insurance program that

allocated funding to

provinces based on

enrolment of beneficiaries

and adding incentives based on indicators of the use and quality MNCH services

Supply side P4P linked to quantity and quality in 8 out of 34 districts

\section{Control)}

duration

End-line Method: Cluster randomized
evaluation trial

Sept 2010- Outcomes: Contraceptive

Dec 2012 prevalence, proportion of deliveries with at least one antenatal care visit, skilled birth attendant, pentavalent 3 vaccination and service utilization
Four health facilities assigned to intervention arm and one health facility assigned to control
End-line evaluation 2004-2008

Method: Cluster randomized trial

Outcomes: Prenatal care visits, tetanus toxoid vaccine, caesarean section, APGAR score at $5 \mathrm{~min}$

Mid-line Method: Mixed methods evaluation design, consisting of a 2010-2011 randomized control trial and qualitative data

Outcomes: Health worker motivation,

ANC services utilization of the five MCH coverage

indicators (modern

contraception, antenatal care, skilled birth attendance, postnatal care, and childhood

vaccination, or in the equity measures

-Substantial increases in the quality of history and physical examinations index and the client counselling index, as well as time spent with patients

-The inattention to demandside factors and difficulty in communicating to health workers about the intervention may have undermined the potential effects of the P4P intervention

- More attention needs to be given to these factors in the design, management, and implementation of P4P programs

$-19 \%$ lower chances of low birth weight $-74 \%$ lower chances in hospital neonatal mortality -Early booking was 34\% higher in treatment group with incentives

-Thoroughness of physical examination and history taking in ANC higher in intervention group compared to the control groups -On average, four additional minutes per patient spent on ANC services

-No significant effect on productivity or presence of staff in their posts

-Greater level of client satisfaction on staff attitude and competence

3200 randomly sampled households

75 randomly selected health facilities from intervention and control provinces
End-line Method: Repeated crossevaluation 2006-2008 (Phase 1) differenal survey, analyzed

2008-2010 Outcomes: Institutional (Phase 2) out nationwide

Bonfrer et al. that started off in one province, scaled up to nine framework vacery, ANC services, vaccination coverages, ITN coverage, child illness episodes, waiting time
-PBF increased the probability of institutional deliveries by $21 \%$, utilization of antenatal care by $7 \%$, and the use of modern family planning methods by $5 \%$

-No effect on vaccination rates and user satisfaction -Government committed to allocate $1.4 \%$ of its budget to performance-based financing and related health financing strategies each year 
Table 1 Description of RBF evaluation reports including evaluation methods and key findings, by country (Continued)

\begin{tabular}{|c|c|c|c|c|c|}
\hline $\begin{array}{l}\text { Country, } \\
\text { Authors, } \\
\text { Year }\end{array}$ & Program Setting & Program coverage & $\begin{array}{l}\text { Evaluation } \\
\text { timing } \\
\text { and } \\
\text { program } \\
\text { duration }\end{array}$ & $\begin{array}{l}\text { Evaluation method and main } \\
\text { outcome measures }\end{array}$ & Key evaluation findings \\
\hline
\end{tabular}

Cameroon Payment of health facility 14 health districts in the De Walque bonus linked to volume and region randomized into et al. (2017) quality of services delivered four arms as follows: in 14 districts in East, South West and North West regions

T1- P4P plus autonomy

C1- Incentive not attached to performance plus autonomy C2- No incentives at all but autonomy C3- No incentive, no autonomy

DRC

World Bank payments to health centres

(2015) [24] and referral centres using a "point system" linked to the volume of targeted services in post conflict HautKatanga District- DRC
Mozambique Phased PBF programs in two Rajkotia provinces Nampula (North) et al. (2017) and Gaza (South) targeting [25] $18 \mathrm{MNCH}$ and / HIV-PMTCT services
One out of eight health district zones health facilities (84 in North, 50 in South)
134 matched facilities

$\begin{array}{ll}\text { End-line } & \text { Method: Randomized control } \\ \text { evaluation } & \text { trial } \\ \text { 2012-2015 } & \text { Outcomes: Child and } \\ & \text { maternal vaccinations, use of } \\ & \text { modern family planning, } \\ & \text { antenatal care visits, facility- } \\ & \text { based deliveries, patient } \\ & \text { satisfaction }\end{array}$
satisfaction

End-line evaluation tria

2009-2013 Outcomes: Cost to patients, health workers' satisfaction, work-related stress and motivation, service utilization, patient satisfaction
End-line evaluation 2011-Sept 2013
Method: Retrospective data (analyzed using propensity score matching)

Outcomes: PMTCT, Paediatric HIV indicators vaccination coverages efficient in bringing payments and funding to provider level, leading to an increased coverage of $\mathrm{MNCH}$ and structural measures of quality of care

-Decreased OOP payments -No difference in $\mathrm{MNCH}$ outcomes between $\mathrm{T} 1$ and $\mathrm{C} 1$ -No effect observed on skilled deliveries and ANC visits

- There was a clear effect of additional financing, irrespective of whether it was linked to incentives

-Increased tendency to over report on volumes, but the tendency fell with increased verification

-Patient records and data quality better in intervention facilities

-Greater transparency and equity in resource allocation among staff

-Significant reduction in absenteeism

-Increased community-based outreach effort

-No change in quality of services in either targeted or non-targeted services -No effect in service utilization -Reduction in job satisfaction -Increased health worker motivation initially, which ultimately reduced intrinsic motivation post intervention

- The majority of the 18 indicators responded to PBF, with at least half of the indicators showing at least 50\% improvement from baseline

-Pregnant women indicators (HIV-infected pregnant women initiating ART and family planning consultations for HIV-infected women) were the only adult HIV indicators that responded to PBF -No adverse effects on nonincentivized indicators point increase in fully
52 Local Government Agencies-LGAs randomised into PBF or DFF and compared with traditional input financing matched states

End-line project evaluation 2012-2016 child health services in three states- Adamawa, Ondo, and Nasarawa
PBF and DFF hybrid

\section{6}

Method: Randomized contro trial (for PBF vs DFF comparison) or a quasiexperimental design (for PB DFF vs 'business as usual' comparison) Outcomes: Skilled birth attendance, fully immunized child, modern contraceptive prevalence, pentavalent 3
-Significant impact of PBF and DFF on key MCH services as well as quality of care (QOC) (relative to 'business as usual'). For example, 14 percentage immunized child coverage and 4.5 percentage point increase in use of modern contraceptives 
Table 1 Description of RBF evaluation reports including evaluation methods and key findings, by country (Continued)

\begin{tabular}{|c|c|c|c|c|c|}
\hline $\begin{array}{l}\text { Country, } \\
\text { Authors, } \\
\text { Year }\end{array}$ & Program Setting & Program coverage & $\begin{array}{l}\text { Evaluation } \\
\text { timing } \\
\text { and } \\
\text { program } \\
\text { duration }\end{array}$ & $\begin{array}{l}\text { Evaluation method and main } \\
\text { outcome measures }\end{array}$ & Key evaluation findings \\
\hline
\end{tabular}

immunization, institutional -Limited difference in terms delivery, antenatal care visits, of QOC indicators and only a equity, CEA modest difference in terms of $\mathrm{MCH}$ services between PBF and DFF

-Both interventions found to be cost-effective and likely to be successful due to decentralization of funds, autonomy given to the facilities, improved supervision, and investments in health systems

Rwanda National supply side PBF Basinga et al. program implemented at (2011) [27] health facility level.
166 district level facilities randomly selected. (intervention group $n=$ 80), (control group $n=86$ )
2006-2010 Method: Randomized control End line trial evaluation

Outcomes: Prenatal care visits, institutional deliveries, quality of prenatal care, child preventive care visits, immunization
166 of Rwanda's 401 primary care facilities, 80 in treatment districts and 86 in comparison districts.
End-line evaluation 2006-2010
Gertler \& program implemented at Vermeersch health facility level
(2013) [28]

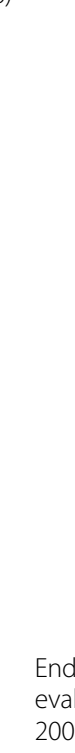

\author{
management
}

- 23\% increases in institutional deliveries in intervention group

$-56 \%$ increase in preventive care visits for 0-23 months age group

$132 \%$ increase in preventive care visits for 23-59 months age group.
- No improvement in the number of women completing four ANC visits or the number of children receiving full immunization
- Increased prenatal care quality measured by Rwandan prenatal clinal guidelines
- Financial performance incentives can improve quantity and quality of $\mathrm{MNCH}$ services and can be in accelerating global development goals

- Substantial improvements in child health outcomes (weight-for-age and heightfor-age $z$-scores)

- Provider incentives led to a

$20 \%$ increase in productivity - Evidence of complementarity between the incentive and the knowledge (skill) of health care providers

Rwanda (c) Complementary community Shapira et al. PBF program

(2017) [29] that rewarded community health worker cooperatives for the utilization of five targeted maternal and child health ser-vices by their communities
End-line Method: Randomized control
evaluation trial

2010-2014 Outcomes: Nutritional status, use of modern contraceptive methods, ANC and PNC services utilization
$-9.6 \%$ increased likelihood to attend ANC within 4 months gestational age.

$-7.2 \%$ increased likelihood to attend PNC within 10 days post delivery

-Financial rewards to the community health workers did not impact on outcome indicators

-No multiplicative effect on outcomes when demand and supply incentives were combined 
Table 1 Description of RBF evaluation reports including evaluation methods and key findings, by country (Continued)

\begin{tabular}{lll}
\hline $\begin{array}{l}\text { Country, } \\
\text { Authors, } \\
\text { Year }\end{array}$ & Program Setting & Program coverage \\
& & \\
\hline Zambia & Performance based & T1: P4P incentives and \\
Friedman & contracting of health centres & medical equipment \\
et al. (2016) & to deliver a specified package & starter packs \\
[30] & of essential MNCH services. & C1: Input based grants \\
& & $\begin{array}{l}\text { and medical equipment } \\
\text { starter packs } \\
\end{array}$ \\
& & C2: nothing was provided.
\end{tabular}

Zimbabwe World Bank (2016) [31]

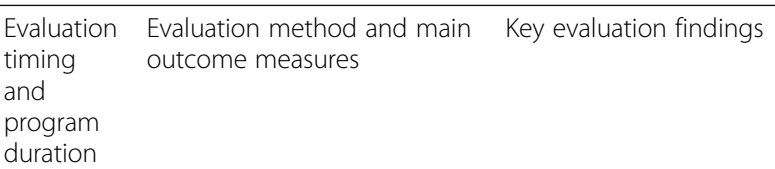

2008-2014 Outcomes: Vaccination coverage, job satisfaction, status of infrastructure-drugs and medical equipment, health services coverage-ANC

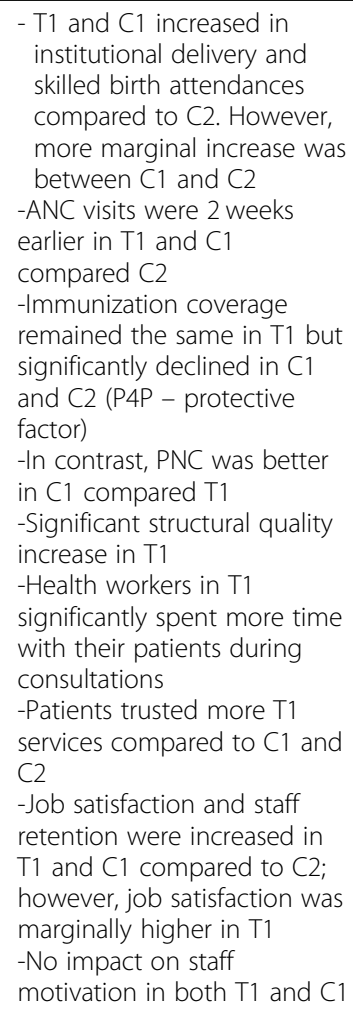
institutional delivery and skilled birth attendances compared to C2. However, more marginal increase was between $\mathrm{C} 1$ and C2

-ANC visits were 2 weeks earlier in $\mathrm{T} 1$ and $\mathrm{C} 1$ compared C2 -Immunization coverage remained the same in $\mathrm{T} 1$ but significantly declined in $\mathrm{Cl}$ and C2 (P4P - protective factor) -In contrast, PNC was better in C1 compared T1 -Significant structural quality increase in $\mathrm{T} 1$ -Health workers in $\mathrm{T} 1$ significantly spent more time with their patients during consultations

-Patients trusted more $\mathrm{T} 1$ services compared to $\mathrm{C} 1$ and C2

-Job satisfaction and staff retention were increased in $\mathrm{T} 1$ and $\mathrm{C} 1$ compared to $\mathrm{C} 2$; however, job satisfaction was marginally higher in $\mathrm{T} 1$ -No impact on staff motivation in both $\mathrm{T} 1$ and $\mathrm{C} 1$

Mid-line Method: Quasi experimental Evaluation design, with data analysed in 2011-2014 a difference-in-difference framework

Outcomes: Skilled birth attendance, MNCH service utilization, family planning, vaccination coverages, nutritional status, client satisfaction, OPP, task shifting
-Improvement in skilled providers, in facility deliveries and caesarean sections outcomes; however, this was also the situation generally across Zimbabwe

-Program did not have negative effect on nonincentives services

-RBF districts had improved autonomy and decentralized decision making -RBF administrative linked tasks aggravated shortage and high workload situation in $\mathrm{HF}$ check selective reporting, the authors inferred the likelihood of bias based on whether the evaluation team seemed independent from the financing agency. Generally, the level of bias was low to medium (Table 3). The remaining sub-sections provide details on countries' typical RBF types, evaluation methods, and evidence on cost-effectiveness.

\section{Common RBF approaches}

RBF tools can be broadly classified into three categories: supply-side with a demand-side component (focus on provider), demand-side with a supply-side component (focus on provider and consumer), and demand-side with no supply-side component (focus on consumer) [18]. Previous reviews have assessed RBF evidence on one or more of these categories [32]. The country-level studies in the current review predominantly fell under the first category. All 13 studies implemented PBF-type programs that had incentives tied to volume, quality, or both.

Typical program setting involved the contracting of health facilities to offer $\mathrm{MNCH}$ services with an 
Table 2 RBF scale-up framework

\begin{tabular}{llll}
\hline Country & $\begin{array}{l}\text { Generation } \\
\text { (conducted a pilot project) }\end{array}$ & $\begin{array}{l}\text { Adoption } \\
\text { (increased scope of pilot either by adding incentivized } \\
\text { indicators or by expanding geographically) }\end{array}$ & $\begin{array}{l}\text { Institutionalization (included RBF as a } \\
\text { part of the national health budget planning) }\end{array}$ \\
\hline Afghanistan & $\sqrt{ }$ & $\sqrt{ }$ & $\sqrt{ }$ \\
Argentina & $\sqrt{ }$ & $\sqrt{ }$ & \\
Benin & $\sqrt{ }$ & $\sqrt{ }$ & \\
Burundi & $\sqrt{ }$ & $\sqrt{ }$ & $\sqrt{ }$ \\
Cameroon & $\sqrt{ }$ & $\sqrt{ }$ \\
DRC & $\sqrt{ }$ & $\sqrt{ }$ & \\
Mozambique & $\sqrt{ }$ & $\sqrt{ }$ & \\
Nigeria & $\sqrt{ }$ & $\sqrt{ }$ \\
Rwanda & $\sqrt{ }$ & $\sqrt{ }$ \\
Zambia & $\sqrt{ }$ & $\sqrt{ }$ \\
Zimbabwe & $\sqrt{ }$ &
\end{tabular}

incentive tied to quantity, quality, or both. Afghanistan's PBF intervention targeted health care providers in 230 health facilities, paying bonus payments of up to $10 \%$ of existing facility contracts to health facilities based on quantity and quality checklists $[19,33]$. Argentina had a similar PBF model, except that payments were made through a national health insurance program that allocated funding to provinces based on enrolment of beneficiaries [20]. Health facility payments in DRC being tied to volume of services provided and not quality was the main difference between the PBF in DRC and those in Argentina, Benin, and Cameroon [20, 21, 23, 24].

The scheme in Rwanda, which was gradually expanded over time, provided both supply- and demand-side incentives. It provided: (i) in-kind incentives (gifts) to women, (ii) performance-based incentives to providers, and (iii) performance-based incentives to community health workers cooperatives for mobilizing mothers to access health services [27, 29]. Nigeria had a unique hybrid of RBF and Decentralized Financing Facility (DFF). In both RBF and DFF approaches, the recipient received direct funding and had autonomy over utilization of those funds. However, in the Nigeria's DFF, the funds were not linked to quantity or quality of services delivered and the staff did not receive any performance bonuses [26].

\section{Evaluation methodologies}

Evaluation methods differed from country to country. The methods ranged from simple before-and-after comparisons to randomized control trials (RCTs). Of the 13 studies, eight were RCTs, one was a repeated cross section analysis, one was quasi-experimental, one was prepost comparison, and one was case control. In most studies, randomization was at the level of the facility or higher, and the effects of the interventions were estimated using a difference-in-difference framework (Table 1).

The vast majority of the studies concentrated on output indicators such as antenatal care (ANC) booking rates and percentage of institutional deliveries, with little or no emphasis on quality or impact measures $[5,22]$. Eleven countries reported an increase in utilization or coverage because of RBF. For example, a 34\% increase in early ANC bookings was recorded in Argentina [20]. Rwanda recorded a 23\% increase in institutional deliveries and a $56 \%$ and a $132 \%$ increase in preventive care visits for children age $0-23$ months and $23-59$ months, respectively [27].

The effect of RBF on health worker motivation in Zambia and the DRC was mixed. In Zambia, there was no significant improvement in staff motivation, whereas there was a $14 \%$ increase in the DRC. However, the effect in the DRC dropped by $25 \% 4$ months after the incentives were removed [24, 30]. RBF in Rwanda and Cameroon had a significant incentive effect in increasing utilization and quality of care for the key $\mathrm{MNCH}$ indicators [23, 27]. There was no difference between the PBF and DFF approaches in Nigeria in terms of their effect on the quality of care. However, there were modest differences in the coverage of key services in favor of the PBF approach [26].

\section{Economic evaluation}

The authors analyzed and presented the economic evaluation results following the Consolidated Health Economic Evaluation Reporting Standards (CHEERS) model [34] (Table 4). Three out of the 13 reports (Argentina, Zambia, and Nigeria) included an economic analysis [20, 22, 29]. All three reports provided a Cost Effectiveness Analysis (CEA). The cost-effectiveness estimates were derived from relatively short program 
Table 3 Risk of bias assessment

\begin{tabular}{|c|c|c|c|c|}
\hline Study & Risk Assessment Parameter & $\begin{array}{l}\text { Assigned } \\
\text { level }\end{array}$ & Basis of judgment & $\begin{array}{l}\text { Assigned } \\
\text { overall } \\
\text { level }\end{array}$ \\
\hline \multirow{6}{*}{$\begin{array}{l}\text { Afghanistan } \\
\text { Cyrus et al., } \\
2015 \text { [19] }\end{array}$} & $\begin{array}{l}\text { Random sequence } \\
\text { generation (selection bias) }\end{array}$ & Low risk & Randomized matched pairs & \multirow[t]{6}{*}{ Low Risk } \\
\hline & $\begin{array}{l}\text { Allocation concealment } \\
\text { (selection bias) }\end{array}$ & Low risk & Sequence generation and allocation happened simultaneously & \\
\hline & $\begin{array}{l}\text { Blinding of participants and } \\
\text { personnel (performance bias) }\end{array}$ & Low risk & Not feasible due to nature of intervention & \\
\hline & $\begin{array}{l}\text { Blinding of outcome } \\
\text { assessment (detection bias) }\end{array}$ & Low risk & Outcome measures identified before the trial & \\
\hline & $\begin{array}{l}\text { Incomplete outcome data } \\
\text { (attrition bias) }\end{array}$ & Low risk & Cluster level of analysis with all clusters remaining in trial & \\
\hline & $\begin{array}{l}\text { Selective reporting (reporting } \\
\text { bias) }\end{array}$ & Low risk & $\begin{array}{l}\text { No evidence of selective outcome reporting, presence of a third-party inde- } \\
\text { pendent evaluator }\end{array}$ & \\
\hline \multirow{6}{*}{$\begin{array}{l}\text { Argentina } \\
\text { Gertler et al., } \\
2014 \text { [20] }\end{array}$} & $\begin{array}{l}\text { Random sequence } \\
\text { generation (selection bias) }\end{array}$ & Unclear & $\begin{array}{l}\text { "... Over time the membership of the treatment and control group } \\
\text { changes." }\end{array}$ & \multirow[t]{6}{*}{ Low risk } \\
\hline & $\begin{array}{l}\text { Allocation concealment } \\
\text { (selection bias) }\end{array}$ & Low risk & Based on initial phased randomized clinics assignment & \\
\hline & $\begin{array}{l}\text { Blinding of participants and } \\
\text { personnel (performance bias) }\end{array}$ & Low risk & Not feasible due to nature of intervention & \\
\hline & $\begin{array}{l}\text { Blinding of outcome } \\
\text { assessment (detection bias) }\end{array}$ & Low Risk & Difficult to ascertain with multiple outcomes & \\
\hline & $\begin{array}{l}\text { Incomplete outcome data } \\
\text { (attrition bias) }\end{array}$ & Low risk & Cluster level of analysis with all clusters remaining in trial & \\
\hline & $\begin{array}{l}\text { Selective reporting (reporting } \\
\text { bias) }\end{array}$ & Unclear & Mix of independent and non-independent consultants & \\
\hline \multirow{6}{*}{$\begin{array}{l}\text { Benin } \\
\text { RBFHealth, } 2014 \\
{[21]}\end{array}$} & $\begin{array}{l}\text { Random sequence } \\
\text { generation (selection bias) }\end{array}$ & Low risk & Quantitative component was based on randomized approach & \multirow[t]{6}{*}{$\begin{array}{l}\text { Medium } \\
\text { risk }\end{array}$} \\
\hline & $\begin{array}{l}\text { Allocation concealment } \\
\text { (selection bias) }\end{array}$ & Unclear & Happened at the same time as sequence generation & \\
\hline & $\begin{array}{l}\text { Blinding of participants and } \\
\text { personnel (performance bias) }\end{array}$ & Low risk & Not likely to be a source of bias & \\
\hline & $\begin{array}{l}\text { Blinding of outcome as } \\
\text { assessment (detection bias) }\end{array}$ & Low risk & $\begin{array}{l}\text { "... any health staff in the } \mathrm{T} 2 \text { group thought that their bonuses were linked } \\
\text { to their performance." }\end{array}$ & \\
\hline & $\begin{array}{l}\text { Incomplete outcome data } \\
\text { (attrition bias) }\end{array}$ & Low risk & Not clear & \\
\hline & $\begin{array}{l}\text { Selective reporting (reporting } \\
\text { bias) }\end{array}$ & Unclear & Evaluation team composition not clear & \\
\hline \multirow{6}{*}{$\begin{array}{l}\text { Burundi } \\
\text { Bonfrer et al., } \\
2013[22]\end{array}$} & $\begin{array}{l}\text { Random sequence } \\
\text { generation (selection bias) }\end{array}$ & High risk & "...rolled out at the provincial level in a non-randomized way." & \multirow[t]{6}{*}{$\begin{array}{l}\text { Medium } \\
\text { risk }\end{array}$} \\
\hline & $\begin{array}{l}\text { Allocation concealment } \\
\text { (selection bias) }\end{array}$ & High risk & "...rolled out at the provincial level in a non-randomized way." & \\
\hline & $\begin{array}{l}\text { Blinding of participants and } \\
\text { personnel (performance bias) }\end{array}$ & Unclear & Not done & \\
\hline & $\begin{array}{l}\text { Blinding of outcome } \\
\text { assessment (detection bias) }\end{array}$ & Unclear & $\begin{array}{l}\text { "Facilities receive payments based on the quality of quality of health } \\
\text { services provided" }\end{array}$ & \\
\hline & $\begin{array}{l}\text { Incomplete outcome data } \\
\text { (attrition bias) }\end{array}$ & Unclear & Attrition not discussed & \\
\hline & $\begin{array}{l}\text { Selective reporting (reporting } \\
\text { bias) }\end{array}$ & Low risk & Different independent consultants with different affiliations. & \\
\hline \multirow[t]{2}{*}{$\begin{array}{l}\text { Cameroon } \\
\text { De Walque } \\
\text { et al., } 2017 \text { [23] }\end{array}$} & $\begin{array}{l}\text { Random sequence } \\
\text { generation (selection bias) }\end{array}$ & High risk & $\begin{array}{l}\text { "... was not feasible given that the Government of Cameroon had already } \\
\text { decided and announced which districts would be included in the PBF } \\
\text { pilot." }\end{array}$ & \multirow[t]{2}{*}{ Medium } \\
\hline & Allocation concealment & High risk & Happened at the same time as sequence generation & \\
\hline
\end{tabular}


Table 3 Risk of bias assessment (Continued)

\begin{tabular}{|c|c|c|c|c|}
\hline Study & Risk Assessment Parameter & $\begin{array}{l}\text { Assigned } \\
\text { level }\end{array}$ & Basis of judgment & $\begin{array}{l}\text { Assigned } \\
\text { overall } \\
\text { level }\end{array}$ \\
\hline & (selection bias) & & & \\
\hline & $\begin{array}{l}\text { Blinding of participants and } \\
\text { personnel (performance bias) }\end{array}$ & Low risk & Not done & \\
\hline & $\begin{array}{l}\text { Blinding of outcome } \\
\text { assessment (detection bias) }\end{array}$ & Unclear & Difficult to assess given the multiple outcomes & \\
\hline & $\begin{array}{l}\text { Incomplete outcome data } \\
\text { (attrition bias) }\end{array}$ & Low risk & Not likely to be a source of bias & \\
\hline & $\begin{array}{l}\text { Selective reporting (reporting } \\
\text { bias) }\end{array}$ & Unclear & Mix of independent and non-independent consultants. & \\
\hline \multirow{6}{*}{$\begin{array}{l}\text { DRC } \\
\text { World Bank, } \\
2015[24]\end{array}$} & $\begin{array}{l}\text { Random sequence } \\
\text { generation (selection bias) }\end{array}$ & Unclear & Not done & High risk \\
\hline & $\begin{array}{l}\text { Allocation concealment } \\
\text { (selection bias) }\end{array}$ & Unclear & Not done & \\
\hline & $\begin{array}{l}\text { Blinding of participants and } \\
\text { personnel (performance bias) }\end{array}$ & Unclear & Not done & \\
\hline & $\begin{array}{l}\text { Blinding of outcome } \\
\text { assessment (detection bias) }\end{array}$ & Unclear & Difficult to assess given the multiple outcomes & \\
\hline & $\begin{array}{l}\text { Incomplete outcome data } \\
\text { (attrition bias) }\end{array}$ & Low risk & Not likely to be source of bias & \\
\hline & $\begin{array}{l}\text { Selective reporting (reporting } \\
\text { bias) }\end{array}$ & Unclear & Part of researchers affiliated to the World Bank & \\
\hline \multirow[t]{6}{*}{$\begin{array}{l}\text { Mozambique } \\
\text { Rajkotia et al., } \\
2017 \text { [25] }\end{array}$} & $\begin{array}{l}\text { Random sequence } \\
\text { generation (selection bias) }\end{array}$ & High risk & $\begin{array}{l}\text { "... attempts to control for selection bias using a two-stage approach. First, } \\
\text { a matching algorithm was implemented to construct a matched compari- } \\
\text { son group for all PBF facilities using propensity scores" }\end{array}$ & $\begin{array}{l}\text { Medium } \\
\text { risk }\end{array}$ \\
\hline & $\begin{array}{l}\text { Allocation concealment } \\
\text { (selection bias) }\end{array}$ & Low risk & Not likely to be a source of bias & \\
\hline & $\begin{array}{l}\text { Blinding of participants and } \\
\text { personnel (performance bias) }\end{array}$ & Low risk & Not done & \\
\hline & $\begin{array}{l}\text { Blinding of outcome } \\
\text { assessment (detection bias) }\end{array}$ & High risk & $\begin{array}{l}\text { ".... we have no way of determining the extent to which improvements in } \\
\text { the intervention group are related to better reporting versus better } \\
\text { performance." }\end{array}$ & \\
\hline & $\begin{array}{l}\text { Incomplete outcome data } \\
\text { (attrition bias) }\end{array}$ & Unclear & Not likely to be a source of bias & \\
\hline & $\begin{array}{l}\text { Selective reporting (reporting } \\
\text { bias) }\end{array}$ & Low risk & Some researchers declared conflict of interest & \\
\hline \multirow{6}{*}{$\begin{array}{l}\text { Rwanda (a) } \\
\text { Basinga et al., } \\
(2011)[27]\end{array}$} & $\begin{array}{l}\text { Random sequence } \\
\text { generation (selection bias) }\end{array}$ & Low risk & Randomization was done by coin toss & Low risk \\
\hline & $\begin{array}{l}\text { Allocation concealment } \\
\text { (selection bias) }\end{array}$ & Low risk & Happened at the same time as sequence generation & \\
\hline & $\begin{array}{l}\text { Blinding of participants and } \\
\text { personnel (performance bias) }\end{array}$ & Unclear & Not done & \\
\hline & $\begin{array}{l}\text { Blinding of outcome } \\
\text { assessment (detection bias) }\end{array}$ & Unclear & Difficult to ascertain to multiple outcomes & \\
\hline & $\begin{array}{l}\text { Incomplete outcome data } \\
\text { (attrition bias) }\end{array}$ & Low risk & Not likely to be a source of bias & \\
\hline & $\begin{array}{l}\text { Selective reporting (reporting } \\
\text { bias) }\end{array}$ & Low risk & No evidence of reporting bias & \\
\hline \multirow{2}{*}{$\begin{array}{l}\text { Rwanda (b) } \\
\text { Gertler \& } \\
\text { Vermeersch, } \\
2013[28]\end{array}$} & $\begin{array}{l}\text { Random sequence } \\
\text { generation (selection bias) }\end{array}$ & Low risk & $\begin{array}{l}\text { "... evaluation employed a stratified cluster randomized designed where } \\
\text { districts were first grouped into pairs with common characteristics and then } \\
\text { randomly assigned to treatment comparison groups" }\end{array}$ & Low risk \\
\hline & $\begin{array}{l}\text { Allocation concealment } \\
\text { (selection bias) }\end{array}$ & Low risk & Happened at the same time as sequence generation & \\
\hline
\end{tabular}


Table 3 Risk of bias assessment (Continued)

\begin{tabular}{|c|c|c|c|c|}
\hline Study & Risk Assessment Parameter & $\begin{array}{l}\text { Assigned } \\
\text { level }\end{array}$ & Basis of judgment & $\begin{array}{l}\text { Assigned } \\
\text { overall } \\
\text { level }\end{array}$ \\
\hline & $\begin{array}{l}\text { Blinding of participants and } \\
\text { personnel (performance bias) }\end{array}$ & Unclear & Not done & \\
\hline & $\begin{array}{l}\text { Blinding of outcome } \\
\text { assessment (detection bias) }\end{array}$ & Unclear & Not done & \\
\hline & $\begin{array}{l}\text { Incomplete outcome data } \\
\text { (attrition bias) }\end{array}$ & Low risk & Not follow up cohort design therefore not likely source of bias & \\
\hline & $\begin{array}{l}\text { Selective reporting (reporting } \\
\text { bias) }\end{array}$ & Unclear & Mix of independent and non-independent consultants & \\
\hline \multirow{6}{*}{$\begin{array}{l}\text { Rwanda (c) } \\
\text { Shapira et al., } \\
2017[29]\end{array}$} & $\begin{array}{l}\text { Random sequence } \\
\text { generation (selection bias) }\end{array}$ & Low risk & $\begin{array}{l}\text { Sectors (sub-districts) in } 19 \text { districts were randomly assigned to different } \\
\text { study arms }\end{array}$ & Low risk \\
\hline & $\begin{array}{l}\text { Allocation concealment } \\
\text { (selection bias) }\end{array}$ & Low risk & Not likely to be a source of bias & \\
\hline & $\begin{array}{l}\text { Blinding of participants and } \\
\text { personnel (performance bias) }\end{array}$ & Low risk & Not feasible for the design & \\
\hline & $\begin{array}{l}\text { Blinding of outcome } \\
\text { assessment (detection bias) }\end{array}$ & Low risk & $\begin{array}{l}\text { "...to measure outcomes prior to the launch of the program, and to } \\
\text { establish internal validity of the study" }\end{array}$ & \\
\hline & $\begin{array}{l}\text { Incomplete outcome data } \\
\text { (attrition bias) }\end{array}$ & Low risk & $\begin{array}{l}\text { "... because the attrition rates were unbalanced between the treatment } \\
\text { arms" }\end{array}$ & \\
\hline & $\begin{array}{l}\text { Selective reporting (reporting } \\
\text { bias) }\end{array}$ & Unclear & Mix of independent and non-independent consultants. & \\
\hline \multirow[t]{6}{*}{$\begin{array}{l}\text { Zambia } \\
\text { Friedman et al., } \\
2016[30]\end{array}$} & $\begin{array}{l}\text { Random sequence } \\
\text { generation (selection bias) }\end{array}$ & Unclear & $\begin{array}{l}\text { "... selecting districts for the IE was based on district-matched } \\
\text { randomization", however due to budgetary limitations population-based } \\
\text { data was only collected in } 18 \text { of the } 30 \text { study districts, leading to the pos- } \\
\text { sible influence of potential unobserved confounders at the district level" }\end{array}$ & Low risk \\
\hline & $\begin{array}{l}\text { Allocation concealment } \\
\text { (selection bias) }\end{array}$ & Low risk & Happened at the same time as sequence generation & \\
\hline & $\begin{array}{l}\text { Blinding of participants and } \\
\text { personnel (performance bias) }\end{array}$ & Unclear & Not done & \\
\hline & $\begin{array}{l}\text { Blinding of outcome } \\
\text { assessment (detection bias) }\end{array}$ & Unclear & Difficult to ascertain to multiple outcomes & \\
\hline & $\begin{array}{l}\text { Incomplete outcome data } \\
\text { (attrition bias) }\end{array}$ & Low risk & Not likely source of bias & \\
\hline & $\begin{array}{l}\text { Selective reporting (reporting } \\
\text { bias) }\end{array}$ & Low risk & No evidence of bias & \\
\hline \multirow{6}{*}{$\begin{array}{l}\text { Zimbabwe } \\
\text { World Bank, } \\
2016[31]\end{array}$} & $\begin{array}{l}\text { Random sequence } \\
\text { generation (selection bias) }\end{array}$ & High risk & $\begin{array}{l}\text { "... These } 32 \text { districts were purposively sampled from a total of } 64 \text { and then } \\
\text { pair matched based on observable factors }\end{array}$ & Medium \\
\hline & $\begin{array}{l}\text { Allocation concealment } \\
\text { (selection bias) }\end{array}$ & High risk & Follows the same risk as random sequence & \\
\hline & $\begin{array}{l}\text { Blinding of participants and } \\
\text { personnel (performance bias) }\end{array}$ & Unclear & Not done & \\
\hline & $\begin{array}{l}\text { Blinding of outcome } \\
\text { assessment (detection bias) }\end{array}$ & Unclear & Difficult considering multiple outcomes & \\
\hline & $\begin{array}{l}\text { Incomplete outcome data } \\
\text { (attrition bias) }\end{array}$ & Unclear & Not reported & \\
\hline & $\begin{array}{l}\text { Selective reporting (reporting } \\
\text { bias) }\end{array}$ & Low risk & No evidence of bias & \\
\hline \multirow[t]{2}{*}{$\begin{array}{l}\text { Nigeria } \\
\text { Kandpal et al., } \\
2019[26]\end{array}$} & $\begin{array}{l}\text { Random sequence } \\
\text { generation (selection bias) }\end{array}$ & High risk & $\begin{array}{l}\text { "... design randomly allocated all the } 52 \text { LGAs in the experimental states to } \\
\text { either the PBF or DFF arms, however while the PBF versus DFF relies on } \\
\text { randomized assignment of LGAs to the two arms, the control comparisons } \\
\text { are based on purposively selected states and are quasi-experimental in } \\
\text { design" }\end{array}$ & $\begin{array}{l}\text { Medium } \\
\text { risk }\end{array}$ \\
\hline & $\begin{array}{l}\text { Allocation concealment } \\
\text { (selection bias) }\end{array}$ & High risk & Happened at the same time as sequence generation & \\
\hline
\end{tabular}


Table 3 Risk of bias assessment (Continued)

\begin{tabular}{|c|c|c|c|c|}
\hline Study & Risk Assessment Parameter & $\begin{array}{l}\text { Assigned } \\
\text { level }\end{array}$ & Basis of judgment & $\begin{array}{l}\text { Assigned } \\
\text { overall } \\
\text { level }\end{array}$ \\
\hline & $\begin{array}{l}\text { Blinding of participants and } \\
\text { personnel (performance bias) }\end{array}$ & Unclear & Not done & \\
\hline & $\begin{array}{l}\text { Blinding of outcome } \\
\text { assessment (detection bias) }\end{array}$ & Unclear & Difficult to ascertain to multiple outcomes & \\
\hline & $\begin{array}{l}\text { Incomplete outcome data } \\
\text { (attrition bias) }\end{array}$ & Unclear & Not reported & \\
\hline & $\begin{array}{l}\text { Selective reporting (reporting } \\
\text { bias) }\end{array}$ & Low risk & No evidence of bias & \\
\hline
\end{tabular}

Note: The risk assessment parameters in this study are taken from the Cochrane Risk of Bias Assessment tool. The tool includes additional parameters. Our analysis utilizes six parameters that are commonly used for evaluating randomized trials on public health interventions

implementation periods ( 2 years and 3 months in Zambia and 4 years in Argentina and Nigeria).

When estimating costs, all studies factored in both fixed and variable costs incurred in program design; planning and management; and implementation. The total program costs for programs in Argentina and Zambia were US \$106 million and \$13.26 million, respectively $[20,30]$. The hybrid PBF-DFF program in Nigeria cost US \$132.9 million [26].

The reports based on Zambia and Nigeria calculated incremental cost effectiveness ratios (ICERs) comparing $\mathrm{PBF}$ to two comparison groups in each case (input financing and no intervention in the case of Zambia and DFF and no intervention in the case of Nigeria) [26, 30]. Depending on the comparison group, ICERs ranged between $\$ 809$ per QALY gained and \$1324 per QALY gained in Zambia (the corresponding range without adjusting for the quality of care was $\$ 999$ to $\$ 1642$ ). Likewise, ICERs ranged between $\$ 300$ and $\$ 458$ in Nigeria (between $\$ 698$ and $\$ 796$ without adjusting for the quality of care). For Argentina, cost effectiveness was estimated by dividing disability-adjusted life years (DALYs) saved due to RBF by incremental costs of the program. The estimated costs per DALY averted were \$814, which was compared to the 2005-2008 per capita GDP of $\$ 6075$ [20]. All three studies found RBF to be cost effective based on the countries' annual GDP per capita [20, 26, 30]. This comparison between DALYs or QALYs against the country's GDP per capita follows the World Health Organization guidelines on the evaluation of public health interventions [35].

\section{Discussion}

Although the development agencies have been encouraging many LMICs to adopt RBF as an important step toward UHC, RBF's institutionalization remains limited. This study reviewed 13 country-specific RBF evaluation reports from 11 LMICs. In an earlier review similar to this review, Witter et al. [32] concluded that almost all dimensions of RBF impact were understudied for both intended and unintended outcomes. Unlike the earlier review, this review focused on country-level evaluations. While substantially more evidence exists now, the country-level evaluations have primarily focused on outputs rather than outcomes. In the logical framework often used for program evaluation, outputs are the immediate results that are delivered by a program whereas outcomes are the next level of effects resulting from the outputs [36]. ${ }^{1}$ Although both measures are useful in understanding the performance of RBF mechanisms, outcomes are more informative since they reveal higher level effects and are more useful for assessing return on investment of the mechanisms.

The improvement observed in structural quality indicators (outputs) at the health facility level is not surprising because RBF mechanisms channel resources to the point of use and foster local autonomy and capacity building.

Only three out of the 13 reviewed reports conducted a cost effectiveness analysis. Given the insufficient evidence on RBF mechanism's cost effectiveness, the low number of countries to have institutionalized RBF is not surprising. The three studies with a CEA followed the World Health Organization's GDP per capital threshold method to determine cost effectiveness. Some researchers have argued that this method may not be very useful to decision makers because it might not reflect national budget priorities, values, and country-specific contexts [37]. Nonetheless, evidence from Argentina, Zambia, and Nigeria suggests that RBF yields better returns on investments than traditional input-based financing strategies.

The current RBF implementation arrangements are complex and have high overhead costs, which can jeopardize the affordability and sustainability of RBF mechanisms even if they are deemed to be cost-effective [38]. Witter et al. [32] argue that paying for performance

\footnotetext{
${ }^{1}$ When a program provides financial incentives to health workers tied to institutional births, the change in the proportion of institutional births is the output, whereas the decline in neonatal mortality is the outcome.
} 
Table 4 Economic evaluation results - CHEERS model

\begin{tabular}{|c|c|c|c|c|c|c|}
\hline Country & Study parameters & Costing & Outcome measurements & $\begin{array}{l}\text { Heterogeneity } \\
\text { characterization }\end{array}$ & $\begin{array}{l}\text { Estimating } \\
\text { tools }\end{array}$ & Key findings \\
\hline $\begin{array}{l}\text { Zambia } \\
\text { Friedman } \\
\text { et al., } \\
2016 \text { [30] }\end{array}$ & $\begin{array}{l}\text { Evaluation period- } \\
2.25 \text { years } \\
\text { Sample size } n=338 \text {, } \\
248 \text { children aged } \\
\text { between } 0 \text { and } 59 \\
\text { months, and } 372,073 \\
\text { women of } \\
\text { childbearing } \\
\text { age. } \\
\text { Comparators- } \\
C_{1} \text { (input financing) } \\
C_{2} \text { (no treatment } \\
\text { group) }\end{array}$ & $\begin{array}{l}\text { Reported based on } \\
\text { programmatic costs } \\
\text { (designing, planning } \\
\text { implementation and } \\
\text { consumables and } \\
\text { supplies) } \\
\text { Total program costs- } \\
\text { US } \$ 13.26 \text { million }\end{array}$ & $\begin{array}{l}\text { Quality and coverage of key } \\
\text { MNCH indicators-vaccination } \\
\text { coverages, family planning, } \\
\text { and institutional deliveries }\end{array}$ & $\begin{array}{l}\text { Results not } \\
\text { reported for } \\
\text { subgroups }\end{array}$ & $\begin{array}{l}\text { Difference } \\
\text { in } \\
\text { difference } \\
\text { approach } \\
\text { Lives } \\
\text { Saved } \\
\text { Tool, QALY }\end{array}$ & $\begin{array}{l}\text {-ICERs were } \$ 1642 \text { per } \\
\text { QALY gained and \$999 per } \\
\text { QALY } \\
\text { gained, when compared } \\
\text { with C1 and C2, } \\
\text { respectively, without } \\
\text { adjustment for the quality } \\
\text { of care } \\
\text {-These ratios improve to } \\
\text { \$1324 per QALY gained } \\
\text { and \$809 per QALY gained, } \\
\text { when compared with C1 } \\
\text { and C2, respectively } \\
\text {-Program established to be } \\
\text { cost effective in terms of } \\
\text { lives saved or QALYS } \\
\text { gained relative to Zambia's } \\
\text { GDP/ capita in } 2013 \\
\text { (\$1759) } \\
\text {-However, this } \\
\text { effectiveness came at a } \\
\text { high unit cost }\end{array}$ \\
\hline $\begin{array}{l}\text { Argentina } \\
\text { Gertler } \\
\text { et al., } \\
2014 \text { [20] }\end{array}$ & $\begin{array}{l}\text { Evaluation period- } 4 \\
\text { years Sample size } \\
n=28,042 \\
\text { Unit of analysis } \\
\text {-pregnant women } \\
\text { and births, } \\
\text { Comparators - No } \\
\text { treatment group }\end{array}$ & $\begin{array}{l}\text { Reported based on } \\
\text { fixed and variable } \\
\text { costs } \\
\text { (medical equipment, } \\
\text { office equipment, } \\
\text { vehicles, and } \\
\text { administration costs } \\
\text { Total program costs- } \\
\text { US } \$ 106 \text { million }\end{array}$ & $\begin{array}{l}\text { Birth weight and neonatal } \\
\text { mortality }\end{array}$ & $\begin{array}{l}\text { Results not } \\
\text { reported for } \\
\text { subgroups }\end{array}$ & $\begin{array}{l}\text { Difference } \\
\text { in } \\
\text { difference } \\
\text { approach } \\
\text { Intention } \\
\text { to Treat } \\
\text { (ITT) } \\
\text { Treatment } \\
\text { on } \\
\text { Treatment } \\
\text { (TOT) }\end{array}$ & $\begin{array}{l}\text {-A DALY saved through } \\
\text { PBF in maternal health } \\
\text { services were } \$ 814 \\
\text {-Program established to be } \\
\text { effective in terms of DALYS } \\
\text { averted relative to 2005- } \\
2008 \text { Argentina GDP/capita } \\
\text { of } \$ 6075 \text {. }\end{array}$ \\
\hline $\begin{array}{l}\text { Nigeria } \\
\text { Kandpal } \\
\text { et al., } \\
2019 \text { [26] }\end{array}$ & $\begin{array}{l}\text { Evaluation period- } 4 \\
\text { years } \\
\text { Unit of analysis } \\
\text {-pregnant women } \\
\text { and children under } 5 \text {, } \\
\text { Comparators - DFF } \\
\text { and } C_{1} \text { (no treatment } \\
\text { group) }\end{array}$ & $\begin{array}{l}\text { Reported based on } \\
\text { PBF implementation } \\
\text { costs and costs for } \\
\text { designing, } \\
\text { implementing, and } \\
\text { monitoring } \\
\text { Costs were rescaled by } \\
\text { population size and } \\
\text { calculated as costs per } \\
\text { capita. } \\
\text { Total program costs- } \\
\text { USD \$132.9 million }\end{array}$ & $\begin{array}{l}\text { Antenatal care, iron } \\
\text { supplementation, postnatal } \\
\text { care, skill birth attendance, } \\
\text { immunization, modern } \\
\text { conceptive use, and children } \\
\text { slept under insecticide- } \\
\text { treated bed nets }\end{array}$ & $\begin{array}{l}\text { Results not } \\
\text { reported for } \\
\text { subgroups }\end{array}$ & $\begin{array}{l}\text { Difference } \\
\text { in } \\
\text { difference } \\
\text { approach } \\
\text { Lives } \\
\text { Saved } \\
\text { Tool, } \\
\text { QALYS }\end{array}$ & $\begin{array}{l}\text {-ICERs of PBF compared to } \\
\text { DFF and control were } \$ 698 \\
\text { and } \$ 796 / \text { QALY gained, } \\
\text { respectively, without } \\
\text { quality of care adjustment } \\
\text {-Ratios fell to } \$ 458 \text { and } \\
\$ 300 / Q A L Y \text { gained after } \\
\text { adjusting for quality } \\
\text {-PBF is cost-effective as } \\
\text { compared to the control } \\
\text { group regardless of } \\
\text { whether life years are ad- } \\
\text { justed for quality. } \\
\text {-Effectiveness of both PBF } \\
\text { and DFF is driven by the } \\
\text { improvements in the } \\
\text { quality of care }\end{array}$ \\
\hline
\end{tabular}

may not always be a good use of resources, even when it is effective, because the potentially small effects are achieved at high costs.

Only two out of the 13 reports in this review included a discussion on sustainability. In Mozambique, on average, it took 18 months of implementation for PBF to show effects, and the impact was generally sustained thereafter [25]. The mobilization of domestic financial resources was central to the sustainability of Burundi's program [22].
The World Bank, the key proponent of RBF, recommends starting at a low and sustainable level of incentives and gradually increasing them based on a robust financial analysis. The World Bank further recommends that $\mathrm{RBF}$ should not be isolated from broader health systems reforms. Instead, it should be viewed as an entry point to tackling system-wide issues [31]. Beyond providing these general directions, the existing literature lacks a meaningful assessment of sustainability of RBF. 
Relatedly, most RBF schemes piloted so far are donor funded [39]. Funding agencies view RBF as a good way to reduce the risk of investing funds when there is a possibility of the results not being achieved [39]. Unfortunately, the resulting dependency of the recipient countries on donors compromises the sustainability of RBF programs. If RBF is to make long-lasting impacts in LMICs, an appetite for reform needs to be created within the country. Simultaneously, the capacity to mobilize domestic resources for RBF needs to be built.

On the basis of the experience of the countries that have institutionalized RBF, the common enabling factors for institutionalization seem to be political will, domestic fund mobilization, and incorporation of demand-side RBF tools. For example, in Burundi, the government allocated $1.4 \%$ of its budget to PBF each year [22]. Rwanda expanded its PBF program to include a demand-side component that incentivized users [29]. In Cameroon, the government doubled its health sector budget to materialize RBF [23]. Insufficient political will and lack of domestic resources seem to be important challenges to institutionalizing RBF [15], which, of course, may be a reflection of a lack of local ownership and insufficient consideration of resource requirements when RBF is first prescribed to countries.

These findings should be understood in light of a number of caveats. Some of the evaluation studies included in the analysis were not conducted by independent evaluators. Rather, they were conducted by the funding agencies themselves, which raises concerns about the level of bias. The positive effects of RBF are likely weaker than reported in this study. Furthermore, the review only studied sources in English and may have missed relevant studies in other languages. Finally, the interventions analyzed were predominantly on the supply-side, leaving the vast number of financial protection-oriented RBF tools, such as user fees exemptions, voucher schemes, and conditional cash transfers to the users. The latter are important ingredients toward the achievement of UHC $[3,29,40]$.

Despite these limitations, the policy implications of these study findings are clear. While political factors may be important in institutionalizing initiatives such as RBF in any country, the evidence on the effectiveness and effects of RBF is so far insufficient. Future research, at a pilot and country level, needs to continuously evaluate RBF schemes, and include qualitative and quantitative research to help define the conditions for successful scale-up, including affordability and sustainability.

\section{Conclusion}

RBF is being promoted as an innovative vehicle toward the achievement of UHC. This review has shown that, while the evidence on the effect of RBF is growing, this evidence is still limited and inconclusive, particularly in areas of costeffectiveness, sustainability, and system-wide long-term impacts. This limited evidence and low local ownership may be some of the reasons behind countries being reluctant to institutionalize RBF. Additional research is needed, particularly on cost-effectiveness, health system-wide impacts, and sustainability of RBF programs.

\section{Abbreviations}

ANC: Antenatal care; CCT: Conditional cash transfer; CEA: Cost effective analysis; CHW: Community Health Worker; DALY: Disability adjusted life years; DFF: Decentralized financing facility; ICERs: Incremental cost effectiveness ratios; GDP: Gross domestic product; HRITF: Health results innovation trust fund; LGA: Local Government Agency; LMIC: Low and Middle-Income Countries; MNCH: Maternal, Neonatal and Child Health; PBF: Performance based financing; P4P: Pay for Performance; PBC: Performance based contracting; QALY: Quality adjusted life years; QOC: Quality of care; RBF: Result based

financing; UHC: Universal health coverage; WHO: World Health Organization

\section{Acknowledgements}

We would like to thank Thomas M. Knarr for editing the manuscript for clarity and language.

\section{Authors' contributions}

$\mathrm{NJ}, \mathrm{KL}$ and YA conceptualized the study. NJ drafted the consolidated matrix, which $\mathrm{KL}$ and $\mathrm{YA}$ assessed for consistency and accuracy. NJ assessed the level of bias, which YA and $K L$ reviewed. All authors contributed in the preparation of the final manuscript and approved it for publication.

\section{Funding}

None.

\section{Availability of data and materials}

All data generated or analyzed during this study are included in this published article.

Ethics approval and consent to participate

Not applicable.

\section{Consent for publication}

Not applicable.

\section{Competing interests}

The authors declare that they have no competing interest.

\section{Author details}

${ }^{1}$ Department of Health Policy and Administration, The Pennsylvania State University, University Park, PA 16801, USA. ${ }^{2}$ Translational Health Research Institute, Western Sydney University, Sydney, Australia. ${ }^{3}$ Hunter Medical Research Institute, Lot 1 Kookaburra Circuit, New Lambton Heights, NSW, Australia.

Received: 4 January 2020 Accepted: 2 June 2020

Published online: 01 July 2020

References

1. Musgrove P. Financial and Other Rewards for Good Performance or Results A Guided Tour of Concepts and Terms and a Short Glossary. World Bank. 2011;(March):1-4. Available from: http://www.rbfhealth.org/sites/rbf/files/ documents/Rewards for Good Performance or Results - Short Glossary.pdf

2. Martinez J, Pearson M, Sorenson BH, James B, Sambo C. Evaluation of the Health Results Innovation Trust Fund; 2012. p. 1-180.

3. World Bank. World Bank Group support to health services achievements and challenges. 2018.

4. Perakis R, Social Finance. Using Results-Based Funding to Drive Health Equity 2016; Available from: http://www.socialfinance.org.uk/wp-content/ uploads/2016/09/SF_ACTION_RBF_Equity_Report_FINAL.pdf. 
5. Grittner AM. Results-based Financing: Evidence from performance-based financing in the health sector. 2013. 1-54 p. Available from: http://www. oecd.org/dac/peer-reviews/Results-based-financing.pdf.

6. Mills A. Health care systems in low- and middle-income countries. N Engl J Med. 2014;370(6):552-7.

7. Brenner S, Mazalale J, Wilhelm D, Nesbitt RC, Lohela TJ, Chinkhumba J, et al. Impact of results-based financing on effective obstetric care coverage: evidence from a quasi-experimental study in Malawi. BMC Health Serv Res. 2018;18(1):1-11

8. White F. Primary health care and public health: foundations of universal health systems. Med Princ Pract. 2015;24(2):103-16.

9. WHO. Maternal Mortality. Maternal mortality factsheet. 2018 [cited 2019 Dec 23]. Available from: https://www.who.int/en/news-room/fact-sheets/detail/ maternal-mortality.

10. Borghi J, Ensor T, Somanathan A, Lissner C, Mills A. Mobilising financial resources for maternal health. Lancet. 2006;368(9545):1457-65.

11. hlarlaithe $\mathrm{MO}$, Grede $\mathrm{N}$, de Pee S, Bloem M. Economic and social factors are some of the most common barriers preventing women from accessing Maternal and Newborn Child Health (MNCH) and Prevention of Mother-toChild Transmission (PMTCT) services: A Literature Review. AIDS Behav. 2014; 18:516-30.

12. McPake B, Witter S, Ensor T, Fustukian S, Newlands D, Martineau T, et al. Removing financial barriers to access reproductive, maternal and newborn health services: the challenges and policy implications for human resources for health. Hum Resour Health 2013;11(1):1-15.

13. Morgan L. Results-based financing for health performance incentives in global health: Potential and pitfalls FEATURE 1. World Bank. 2016;6. Available from: http://www.rbfhealth.org/sites/rbf/files/RBF_FEATURE_ PerflncentivesGlobalHealth.pdf.

14. Shroff ZC, Tran N, Meessen B, Bigdeli M, Ghaffar A. Taking results-based financing from scheme to system. Heal Syst Reform. 2017;3(2):69-73.

15. Shroff ZC, Bigdeli M, Meessen B. From scheme to system (part 2): findings from ten countries on the policy evolution of results-based financing in health systems. Heal Syst Reform. 2017;3(2):137-47.

16. Hjort J, Moreira D, Rao G, Santini JF. How Research Affects Policy: Experimental Evidence From 2,150 Brazilian Municipalities. NBER Work Pap Ser. 2019;25941:1-60 Available from: https://www.socialscienceregistry.org/ trials/4273.

17. World Bank. World Bank Country and Lending Groups [Internet]. [cited 2019 Nov 21]. Available from: https://datahelpdesk.worldbank.org/ knowledgebase/articles/906519-world-bank-country-and-lending-groups.

18. Gorter A, Ir M, Meessen B. Results-based financing of maternal and newborn health care in low- and lower-middle-income countries. ... Matern Newborn Heal ... [Internet]. 2013;(February). Available from: https://search. oecd.org/dac/peer-reviews/Evidence-RBF-maternal-health.pdf.

19. Engineer $C Y$, Dale E, Agarwal A, Agarwal A, Alonge O, Edward A, et al. Effectiveness of a pay-for-performance intervention to improve maternal and child health services in Afghanistan: a cluster-randomized trial. Int J Epidemiol. 2016;45(2):451-9.

20. Gertler P, Giovagnoli P, Martinez S. Rewarding provider performance to enable a healthy start to life: evidence from Argentina's Plan Nacer. Policy Res Work Pap World Bank. 2014;6884:1-35 Available from: http://www-wds. worldbank.org/external/default/WDSContentServer/IW3P/IB/2014/05/21/ 000158349_20140521140101/Rendered/PDF/WPS6884.pdf.

21. RBFHealth. Benin Impact Evaluation. [cited 2019 Dec 23]. Available from: https://www.rbfhealth.org/impact-evaluation/benin-impact-evaluation.

22. Bonfrer I, Soeters R, Van de Poel E, Basenya O, Longin G, van de Looij F, et al. Introduction of performance-based financing in Burundi was associated with improvements in care and quality. Health Aff. 2014;33(12): 2179-87.

23. de Walque D, Robyn PJ, Saidou H, Sorgho G, Steenland M. Looking into the Performance-Based Financing Black Box. Evidence from an Impact Evaluation in the Health Sector in Cameroon. 2017;(August):2-29.

24. The World Bank. Impact evaluation on Performance Based Financing in Haut-Katanga District, DRC. 2015;1-44. Available from: https://www. rbfhealth.org/sites/rbf/files/Impact Evaluation on PBF in Haut Katanga District - DRC.pdf.

25. Rajkotia Y, Zang O, Nguimkeu P, Gergen J, Djurovic I, Vaz P, et al. The effect of a performance-based financing program on HIV and maternal/child health services in Mozambique - an impact evaluation. Health Policy Plan. 2017;32(10):1386-96.
26. Kandpal E, Loevinsohn BP, Vermeersch CMJ, Pradhan E, Khanna M, Conlon MK, et al. Impact Evaluation of Nigeria State Health Investment Project. World Bank Gr Open Knowl Repos. 2019.

27. Basinga P, Gertler PJ, Binagwaho A, Soucat AL, Sturdy J, Vermeersch CM. Effect on maternal and child health services in Rwanda of payment to primary health-care providers for performance: an impact evaluation. Lancet. 2011;377(9775):1421-8 Available from: https://doi.org/10.1016/ S0140-6736(11)60177-3.

28. Gertler P, Vermeersch C. Using Performance Incentives to Improve Medical Care Productivity and Health Outcomes. NBER Work Pap Ser. 2013:19046 Available from: http://www.nber.org/papers/w19046.pdf.

29. Shapira G, Kalisa I, Condo J, Humuza J, Mugeni C, Nkunda D, et al. Effects of Performance Incentives for Community Health Worker Cooperatives in Rwanda. 2017;(May):34. Available from: http://documents.worldbank.org/ curated/en/573571494939902839/pdf/WPS8059.pdf.

30. Friedman J, Qamruddin J, Chansa C, Das AK, The World Bank Group. Impact Evaluation of Zambia's Health Results-Based Financing Pilot Project; 2016. p. 81. Available from: https://www.rbfhealth.org/impact-evaluation/ghanaimpact-evaluation.

31. The World Bank. Rewarding provider performance to improve quality and coverage of maternal and child health outcomes. 2016.

32. Witter S, Fretheim A, Kessy FL, Lindahl AK. Paying for performance to improve the delivery of health interventions in low- and middle-income countries. Cochrane Database Syst Rev. 2012;2012:2.

33. Kandpal E. Completed impact evaluations and emerging lessons from the health results innovation trust fund learning portfolio: World Bank Group Open Knowledge Repository; 2016.

34. Husereau D, Drummond M, Petrou S, Carswell C, Moher D, Greenberg D, et al. Consolidated Health Economic Evaluation Reporting Standards ( CHEERS ) statement Stable URL : https://www.jstor.org/stable/42002232 Linked references are available on JSTOR for this article : ( CHEERS ) statement Consolidated Health Economic Evaluation Re. 2019;14(3):367-72.

35. Marseille E, Larson B, Kazi DS, Kahn JG, Rosen S. Thresholds for the costeffectiveness of interventions: alternative approaches. Bull World Health Organ. 2015;93(2):118-24.

36. Africa Development Bank. Guidelines for Preparing a Design and Monitoring Framework. Business. 2007. Available from: http://www.adb.org/documents/ guidelines/guidelines-preparing-dmf/guidelines-preparing-dmf.pdf.

37. Bertram MY, Lauer JA, De Joncheere K, Edejer T, Hutubessy R, Kieny M-P, et al. Policy \&amp; practice cost-effectiveness thresholds: pros and cons thresholds based on gross domestic product. Bull World Heal Organ. 2016; 94(September):925-30 Available from: https://doi.org/10.2471/BLT.15.164418.

38. Witter S, Chirwa Y, Chandiwana P, Munyati S, Pepukai M, Bertone MP, et al. Results-based financing as a strategic purchasing intervention: some progress but much further to go in Zimbabwe? BMC Health Serv Res. 2020; 20(1):1-18.

39. Eldridge M, Tekolste R. Results-Based Financing Approaches Observations for Pay for Success from International Experiences RBF Approaches in Developing Countries. 2016;(November):8-14.

40. Parmar D, Banerjee A. How do supply- and demand-side interventions influence equity in healthcare utilisation? Evidence from maternal healthcare in Senegal. Soc Sci Med. 2019;241 (august):112582 Available from: https://doi.org/10.1016/j.socscimed.2019.112582.

\section{Ready to submit your research? Choose BMC and benefit from:}

- fast, convenient online submission

- thorough peer review by experienced researchers in your field

- rapid publication on acceptance

- support for research data, including large and complex data types

- gold Open Access which fosters wider collaboration and increased citations

- maximum visibility for your research: over $100 \mathrm{M}$ website views per year

At $\mathrm{BMC}$, research is always in progress.

Learn more biomedcentral.com/submission 